\title{
Integrating the cosmopolitan and the local: The curricular construction of citizens in Luxembourg in the long 19th century
}

\author{
Integrando lo cosmopolita y lo local: La construcción curriculuar de los \\ ciudadanos en Luxemburgo a lo largo del siglo XIX
}

Intégrer le cosmopolite et le local: La construction des citoyens au programme scolaire du Luxembourg au 'long dix-neuvième siècle

\section{Catherina Schreiber}

University of Luxembourg, Luxembourg

\begin{abstract}
During the 19th century new forms of government emerged, understanding themselves explicitly as nation-states. The new definition of the state had to include its members by defining them as citizens, a definition which included both equalizing and differentiating aspects. The education system fulfilled a key role in educating these future citizens. While the principal setting was not a national, I intend to show how this national logic shaped constructions of various types of nation-state citizens made through the public school, based on empirical evidence from the Luxembourgian curriculum. In an exemplifying way, the motivation behind the respective changes and continuities will be uncovered, with emphasis on social differentiation in secondary education and a strong regional differentiation in the homebound lower branches of education.
\end{abstract}

Key words: curriculum history, citizenship, nation-state schooling, cosmopolitanism, social differentiation, idiosyncracy.

\section{RESUMEN}

Durante el siglo XIX emergieron nuevas formas de gobierno, las cuales se autodenominaron explícitamente como naciónes-estado. La nueva definición de estado tenía que incluir a sus miembros mediante la definición de los mismos como ciudadanos, una definición que incluía aspectos igualizadores y diferenciadores. El sistema educativo complió un rol clave en la educación de esos futuros ciudadanos. Si bien el contexto principal no fue nacional, intento mostrar cómo esta lógica nacional dio 
forma a contrucciones de diferentes tipos de ciudadanos del estado-nación llevado a cabo mediante la escuela pública basándome en evidencias empíricas del curriculum de Luxemburgo. De una forma ejemplificante, la motivación detrás de los respectivos cambios y continuidades serán descubiertas con referencia a la diferenciación social en educación secundaria y una fuerte diferenciación regional en las ramas bajas confinadas de educación.

Descriptores: Historia del curriculum, ciudadanía, escolarización del estado-nación, cosmopolitismo, diferenciación social, idiosincrasia.

\section{RESUME}

$\mathrm{Au}$ cours du $19 \mathrm{e}$ siècle de nouvelles formes de gouvernement émergèrent qui se définissaient explicitement comme États-nations. La nouvelle définition de l'État devait inclure ses membres en les définissant comme citoyens, une définition comprenant des aspects égalisateurs et d'autres, différenciateurs. Le système éducatif remplissait un rôle-clé dans l'éducation de ces futurs citoyens. Quoique le cadre principal ne fût pas national, je me propose de démontrer comment cette logique nationale a façonné une variété de types de citoyens des États-nations par l'école publique. Je me base sur l'évidence empirique des programmes d'études Luxembourgeois. À titre d'exemple, j'expose la motivation sous-jacente aux changements et aux continuités concernant la différenciation sociale dans l'éducation supérieure et une forte différenciation régionale aux secteurs inférieurs plus près de la famille.

Mots clés: I'histoire des programmes éducatifs, la citoyenneté, l'éducation assurée par l'État-nation, le cosmopolitisme, la différenciation sociale, l'idiosyncrasie.

\section{Introduction}

In Douglas Adams' The Hitchhiker's Guide to the Galaxy (1981), the eponymous hitchhiker comes to the eventual insight that the enormous supercomputer Deep Thought, over millions of years, has calculated the answer to the ultimate question on "the meaning of life, the universe, and everything": 42. Unfortunately, the programmers did not provide Deep Thought with a precise question, so in the end they are left with an answer that is meaningless by itself.

Concepts like "citizen" and "citizenship" act as answers offered to our contemporary societies much like the 42 in The Hitchhiker's Guide - and like their fictional counterpart, they are missing the vital context of what problem "the citizen" was actually meant to solve, or which question they were supposed to answer that could make consistent reason out of them. In current research, the vision of citizenship is often embedded in the rhetoric of democracy, participation, inclusion, and justice, ${ }^{1}$

\footnotetext{
${ }^{1}$ These attributions to the citizen become apparent in the range of composite phrases linked to it, be it transnational or global citizenship, the active citizen, the differentiated citizen, the (personally) responsible
} 
increasingly offering self-determination, a political voice, and full maturity. Research on citizenship has experienced an accelerated upturn since the 1980s (Cogan \& Derricott, 2000; Ichilov, 1998), mainly evolving around three areas - a shift in the meaning of citizenship towards democracy, active responsibility, and the awareness of pluralism in societies. This triggered a perceived need to redefine citizenship, as well as increasing literature on the influence of globalization or (in the European context) Europeanization on citizenship (for example, Balibar, 2004; Falk, 1994).

By these rhetoric patterns, the citizen is turned into a metacode ${ }^{2}$ : veiling the tensions and contradictions, within which the citizens were formed, citizenship though not being self-explanatory when addressed in different concepts - seems to be based on "an objective mode of behavior" (Heater, 2003, p. 155). Such universal and global notions of citizenship are based on inherent teleological thinking; not only do they claim to depict simply a mode of existence, thereby decoupling citizenship from its manifold contexts and turning it into a flexible container empty of meaning, global theories of citizenship also tend to think in waves of reform. ${ }^{3}$ Differences between countries are explained by the perspective that, when the global model of schooling changes, the latest version does not reach the whole globe at the same time. This assumes a gradient of modernity between a universal, global citizenship and a nationally confined citizenship, in which some states might be seen as having "fallen behind" (as discussed in Anderson-Levitt, 2003, p. 20).

Typical vocabulary are terms like "transitions" and "transformations" of citizenship or even the "decline" of the nation-state citizen (as in Falk, 2000; Gowar, 2008; Joppke, 2007). Also, so far, within this narration of an international gradient, research on civic education has privileged "some values and practices of liberal democracy which endorses some sense of common identity" (Haydon, 2003, p. 8), in which difference is suppressed in favor of the creation of equality and symmetry (Benhabib, 1996, p. 70). De Oliveira Andreotti and Mario de Souza (2012) for instance have shown how global citizenship education often "results in educational practices that unintentionally reproduce ethnocentric, ahistorical, depoliticized, paternalistic, salvationalist and triumphalist approaches that tend to deficit theorize, pathologize or trivialize difference" (p.1). Although different concepts (such as Marshall, 1950) have broadened the notion of citizenship to a social dimension, integrating societal differences into the concept of citizenship education became even more difficult. Criticisms of too narrow definitions of citizenship followed (Arnot et al., 1996; Prokhovnik, 1998; Richardson, 1998). Foucault-oriented studies (such as Rose, 1999; Rose \& Miller, 1992) on governmentality for example claimed that citizenship should

citizen, the neo-republican citizen, cultural or even multicultural citizenship, or the consuming citizen. And while claiming universality, these compounds at the same time already construct a hierarchical order that excludes everybody from citizenship not fitting under the compounds: the active excludes the passive citizen, the responsible excludes the irresponsible citizen, and so on.

${ }^{2}$ As defined by Hayden White (1981) as "a human universal on the basis of which transcultural messages about the nature of a shared reality can be transmitted" (p. 1).

${ }^{3}$ Two examples of this are the "waves-of-civilizations-model" triggered by Alvin and Heidi Toffler (1980) and the neo-institutionalist world culture theory discussed by, for example, Meyer, Ramirez, and Soysal (1992). ? 
not only be considered as a legal status certifying political rights and obligations, but also as shaping forms of subjectivity. Here, citizenship "more profoundly serves as a means of social differentiation and of fabricating interests, opinions, and preferences" (Olson, 2008, p. 40). Recent research approaches have addressed the multiple cultural and social movements that either buttressed or challenged hegemonic projects. ${ }^{4}$ Yet still both aspects, equalization and differentiation of citizens, are often constructed in an artificial dichotomy.

This article explores another possibility of historicizing the citizen that does not assume a teleological development from a nationally confined to a broader citizenship. To historicize the nation-state citizen, it is thus necessary to find an alternative modus operandi. On one hand, it should take the historically and culturally based normative values behind citizenship concepts into account. On the other hand, it should at the same time abstract from any narrowed and particular normative view of citizenship when looking at the curricular negotiations.

Instead, I argue in a first part, that a distinction has to be made between the heuristic code of nation-state citizenship and its actual cultural-political definition. The fabrication of the citizen through the education system again is studied through the conception of curriculum as the product of manifold expectations and experiences and complex social negotiations in a specific historical situation, which allows us to look at all schooling experiences in their entirety with their entrenchment in the educational system, their dependency of cultural and societal processes, and their reciprocal interaction. The article assumes Luxembourg as a case in order to understand curricula in their broader cultural-historical context. By investigating the twofold character of curricular negotiations in Luxembourg including equalizing and differentiating elements at the same time, the motivations and ways of reasoning of the nation-state will be uncovered behind concrete curricular examples between 1839 and 1939 that can only be understood in a histoire de longue durée (Braudel, 1949, pp. 13-14). This article uses the case of secondary education in Luxembourg, where since the $19^{\text {th }}$ century a dualism has been constructed between cosmopolitan Bildung (education) and homebound Volksbildung (mass education) - a dualism that also found its representation in the linguistic terms of postprimary education (enseignement postprimaire or also cours postscolaires) vs. secondary education (enseignement sécondaire). ${ }^{5}$

With this, I intend to show that the ideal of cosmopolitan citizenship for the Luxembourgian elite is an expression of a "logic" of the nation-state establishing

\footnotetext{
${ }^{4}$ Admittedly, the fact that citizenship is individually constructed and exerted under the influences of an all but symmetric and equal society indeed has been addressed (Kymlicka, 2001; Richardson \& Blades, 2006). The consequences for citizenship have been considered, foremost in terms of verticality and exclusion, to mention one of the most fruitful of Pateman's discussions on how citizenship is constructed "from men's attributes, capacities and activities," so that citizenship can only be extended to women "as lesser men" (Pateman, 1988, pp. 252-253; Pateman, 1992).

${ }^{5}$ Historically, the term of postprimary education was used all for educational tracks following primary school that were not regarded as secondary schools, whereas the term of secondary education was reserved for the high schools qualifying for academia.
} 
differentiated notions of education as a national resource, rather than a step of international transformation. At the same time, the construction of various postprimary educational possibilities - interpreted as steps of an international modernization to implement the civic ideals of justice, equality, and full maturity into the public school systems - were used to construct different kinds of homebound national citizens. Hence, despite their rhetoric of inclusion, the inward distinction between "cosmopolitan" and "homebound" established a strong social differentiation in secondary education as a need of the small and young Grand Duchy.

\section{Towards a heuristic understanding of citizenship}

In the course of the 19th century new forms of government emerged, understanding themselves explicitly as nation-states. The new definition of the state had to include its members by defining them as citizens, thereby publicly establishing a formal equity and unity among them with their constitutions. However, these "citizens" were not born but had to be "manufactured" (Bénéï, 2005) according to manifold and partly conflicting local, national, and cosmopolitan expectations (ibid.; see also Cruikshank, 1999; Tröhler, Popkewitz, \& Labaree, 2011).

While the principal setting - the foundation of nation-states throughout territorial Europe in the 19th century and the construction of their citizens - was not a national phenomenon, it was realized in varying shapes and degrees from nation-state to nation-state dependent on the cultural context. Yet the heuristic term of nation-state citizenship addresses only the process of defining the members of the state, and therefore describes the same phenomenon in each nation-state.

The heuristic citizens of the nation-state can be interpreted as outplays of a specific logic of the nation-state comprising several fundamental narratives of nationstate school systems:

- Discourses on nation-state citizenship claim the nation-state to be dependent on national progress (for example, as described in Lemberg, 1964, pp. 52-53), which can only be achieved if everybody fulfills their functions, and this function cannot be determined by the individuals themselves.

- They likewise think of the nation-state as in need of a functioning economic and societal system (see Schreiber, 2014). For this, it needs its citizens to fulfill specific roles, which require the existence of certain equalizing and differentiating techniques.

- Such dedication of the individual state member to his or her role should be based on the individuals' understanding contribution to society. ${ }^{6}$ In Luxembourg, for instance, educational efforts aimed at "willing workers" (Fortbildungsschüler, 1916), "loving" Luxembourgers (Koenig, 1914), and "insightful tax payers"

\footnotetext{
${ }^{6}$ As pointed out by Hobsbawm and Ranger, nationalism tended to equate two entirely different phenomena with each other: a collective consciousness and the formation of the nation-state as a system of government, allegedly grounded on this collective consciousness (Hobsbawm \& Ranger, 1992). Determinism, and heteronomy, did not literally match this conception of the nation-state.
} 
(Mémorial A, 1916, p. 1125). These insights, however, do not come naturally, but have to be mediated. In the educationalized nation-states such as in the case of Luxembourg, the curriculum served as a reliable variable for the construction of nation-state citizenry.

I deliberately used citizens in plural form, above, to note that a consistent notion of citizenship did not exist: beyond its equalization of all inhabitants as citizens, differentiation within the nation was also an essential part of the national citizenship education. The construction of this nation-state citizenship hence served a double purpose, which was firstly the creation of national unity and equality in the sense of an imagined community (Anderson, 1983) and secondly differentiation within the nation.

On one hand, a society of formally equal nation-state citizens was brought about by the new constitutions after the Congress of Vienna in 1815. This exceeded the legal frame, as the intended union of the nation was well supported by emphasizing characteristic features supposed to be national as well as uniting elements (Hobsbawm \& Ranger, 1983), accompanied by the perception of national particularities: "And there were as many 'exceptionalisms' in that era as there were nations" (Kamens, 2012, p. 15). On the other hand, this posed the question on how to legitimate enduring or recently emerging societal differences or even make them compatible with this promise of unity and equality. Anderson (1983) especially emphasized how the national elites used the imagined community for further societal differentiation.

Societal differences, which had already existed before the national unification, lingered and were legitimized nationally, as the new citizens were manufactured based on the former society - with all its societal differentiation and heteronomy - in a process of "metamorphosis" of subjects into citizens (Geertz, 1973, pp. 269-270; see also Bénéi, 2005, p. 14). Furthermore, the existing differences were also replenished by the societal categorization of the nation-state: the nation-state approached existing differences with a more systematic understanding.

New, nationally legitimated administrative elites emerged: the "guardians of state and society" (Kamens, 2012, p. 91). The closer the proximity to the center of the nation and its institutions, the more charisma was attached to their positions and persons (ibid., pp. 16-17). Both elements (equality and differentiation) are inevitably included in the making of citizens of the nation-states. In Luxembourg, as my empirical examples will show, the construction of such different kinds of citizens was exactly based on the distinction of regional and international categories within the nation. Yet, with the Luxembourgian educational elite dominating the curricular discussions, differences in classes were not only the outcome of different citizenship constructions, but were themselves constructed as a persistent trait of Luxembourgianity, revealing a complex notion of education that should be adapted to various needs of differentiation.

\section{Bildung and Volksbildung as a national need}

Luxembourgers, so several teachers' journals stated, were supposedly "educable and particularly capable of a many-sided education" (Luxemburger Schulfreund, 1884, p. 
166). The importance of education as a national need served as a nodal point for national identity discourse, enacting learnability and adaptability as the basis of a Luxembourgian "mixed culture" with French and German elements, increasingly naturalizing a well-trodden token of the construction of national unity: the importance of education as a national need. On one hand, the independence of 1839 had left the Grand Duchy in reliance upon a strong educational elite ${ }^{7}$ triggering a discourse about the importance of knowledge and education, which linked notions of humanist, general Bildung to a proclaimed international objectivity as qualities of the educated bourgeoisie. Secondary school teachers like Frantz Clément and Nicolas Ries deducted the national psychology from a transnational struggle:

"Two cultural constructions have been fighting [...] over our soul: the French and the German one. [...] As a consequence of mundane influence we feel the need to organize things clearly. [...] Our eclecticism is system." (Tageblatt, 12 August 1921)

"With defining pedantry in researching, creativity and desire for clarity as national traits, these discourses established an understanding Luxembourg at the crossroads of European intellectual development that however, so the concern, should not stick to a 'licking at cultures,' but should strive for Luxembourgian 'originality.'” (Tageblatt, 22 August 1921)

"The international importance of Luxembourg, so the renowned teacher Frantz Clément concluded, would be owed to the intelligence and energy of its citizens, but Luxembourg would have to do its utmost in all areas education to achieve national harmony that would contemporarily be disturbed by too much emphasis on purely economic values." (Tageblatt, 11 October 1923)

On the other hand, the discourses on educability as a national particularity also incorporated practical notions of Volksbildung (mass education) that were much more homebound and locally oriented and intended for the education of the lower classes only (Tageblatt, 25 October 1916). Again, knowledge and education were meant to make the country competitive and guarantee its existence, yet not by means of classical Bildung, but as usable knowledge and character formation. While stating the significance of knowledge for the Grand Duchy in general - "We are a people thirsty for education" (Luxemburger Wort, 13 September 1911) - romanticizing notions hid the

\footnotetext{
${ }^{7}$ One could state that the educated bourgeoisie was the only group able to make up Luxembourg's elite, due to the almost complete loss of Luxembourg's nobility except for the grand-ducal family and a lack of influential landowners: although $3 / 4$ of the Luxembourgian population were involved in farming and grocery, the land was parcelled into smallest pieces. Politically, Luxembourg was in need of proper doctors, priests, teachers/professors, and lawyers. Since Luxembourg had no university, they had to complete their studies abroad, which served as a further legitimation for their societal influence as the cosmopolitan avantgarde and was considered a necessary requirement for an intellectual, cultural, and scientific expansion of Luxembourg's horizons.
} 
fact that there have been different notions of Bildung reflecting and reinforcing differences in classes, gender, professions, and social status: "Across the globe the call has been cast forth for increased Volksbildung: Bildung shall as much as possible become a common good of all" (Luxemburger Wort, 29 August 1872).

Notwithstanding this inclusive notion, the argumentation stepped from education as common good to the need of differentiation, explaining that this demand was limited to certain knowledge that might be useful in specific - foremost economic contexts: "This call has its explanation and justification in the increased necessaries of our modern life, in the progressing extension of commerce and industry, [...] modern science increasingly applicable to ordinary life" (ibid.).

Volksbildung was explicitly dedicated to raising the working morale: "The more enlightened a people is, the harder it works" (Luxemburger Wort, 30 August 1871). Made up as essential for the Luxembourgian autarchy, it linked utilitarian notions of useful and practical knowledge from the students' immediate environment to specific moral values (pacifism, patriotism, Christianity, and sense of community). On one hand, this was to guarantee optimal job preparation; on the other hand, the authorities were aiming at the social and moral education of the future workers, fearing for the autarchy and competitiveness of the small Luxembourgian state (Lenz, Rohstock, \& Schreiber, 2013 , p. 317). Not only did propagators of Volksbildung consider the school responsible for educating "the worker in the human partnership of convenience" (Wagner, 1935, p. 25), but also "an army of glad and producing workers" (Fortbildungsschüler, 1916, p. 128).

The dichotomy between Bildung and Volksbildung is mirrored by other dichotomist constructions: the laws of Luxembourg started to expand access to education beyond primary education at the end of the 19th century. However, they introduced separate school types somewhere in between primary and secondary education, categorized under "postprimary education." This included the upper primary schools ${ }^{8}$ and the continuing classes, ${ }^{9}$ two school forms that provided two more years, hence establishing a distinctly recognizable postprimary sector separate from secondary education, with the focus on the "needs of modern time," defined as religiosity, morality, sense of justice, obedience, modesty, thriftiness, politeness, and patriotic love (Luxemburger Schulbote, 1892, p. 136). The pairs of educational terms used to contrast the lower educational tracks with the classical secondary schools were typical: homeboundedness was contrasted with cosmopolitanism; commonality with individuality; "realities" education with "humanist," "universal," or "general" education; practical with theoretical knowledge; functional with aesthetic aims; material and professional instruction with formal education. I will now carve out this dualism by a

\footnotetext{
${ }^{8}$ Upper primary schools (Oberprimärschulen) had gradually developed within the course of the second half of the nineteenth century, without a legal base existing for it. They offered a two year curriculum after primary school.

${ }^{9}$ Continuing classes (Fortbildungsschulen) likewise offered two more years of schooling after primary school, but with a specific focus on professional preparations of the future workers for very specific social values such as discipline, orderliness, and thriftiness (Emmel, 1988, p. 229).
} 
curricular comparison.

\section{Postprimary schools for Christian peasants and workers}

Since the mid-19th century, Luxembourgian newspapers had pilloried the compulsion to send students from lower social classes to French or Belgian schools after primary school. The returning students would be "foreigners in their own fatherland" (Wächter an der Sauer, 29 March 1862). While the Luxembourgian elite enacted itself as cosmopolitan and spent parts of their education abroad, this did not seem desirable for the lower achievement classes, because it would not allow the students to acquire useful knowledge, such as the "veneration to the national laws" or "sentiment for the national habits and customs and mores" (ibid.).

New school types were hence created, the continuing classes, which more than any other school type were oriented towards a homebound education for the future life in society. The curriculum scheduled a less formal and more usability-oriented adult education. With this provision, postprimary education connected with the concepts of primary education, but in a more professionally oriented way, and thus reflects curricular patterns of the primary school discussions framing education as a medium to prepare the students for practicing social and Christian virtues (Mémorial A, 1881, p. 374), but not at all preparing for any academic track. ${ }^{10}$ Whereas secondary education prepared its students for their stay abroad, postprimary education was overall homebound. Its curricular approaches show a distinct orientation towards realities (Realia) and usefulness, excluding everything that had the character of "general, abstract, theoretical and systematical studies" as intended for secondary education (Luxemburger Schulbote, 1870, p. 208). The criterion of "usefulness" assumed a consensus about what and who was included, and thus embodying processes of abjection (Popkewitz, 2008, p. 148). Two of these patterns shall be presented in more detail:

- Catholic notions of morale shaped the curriculum, seeing education foremost as a medium to combat a perceived moral deficit, evident in the disaggregation of family, alcoholism, diseases, or missing sexual morale (see, for example, ANLux IP-2873, 1917; Luxemburger Schulbote, 1870, pp. 216f.). These Catholic notions of morale were closely linked to the promotion of "national sentiment and public spirit." One strong key symbol for the Luxembourgian independence implemented in postprimary education was the monarchy, to which the curriculum established an intense emotional relationship - Luxembourgers, so the Schulfreund, were "born with great loyalty towards the ducal house" (Luxemburger Schulfreund, 1885, p. 28). Even when education in secondary schools distanced itself explicitly from "lopsided nationalistic" (ANLux IP-607, 1922) perspectives of the Luxembourgian history in favor of a pacifist

\footnotetext{
${ }^{10}$ A change or transfer between the different school types, namely from postprimary education to secondary education, was hard to realize for students of upper primary schools and literally impossible (since not intended by law) for students of continuing classes. However, a successful attendance of upper primary schools could facilitate the entrance to a secondary school (or the Normal school) afterwards.
} 
international cultural history, postprimary school branches stuck to the monarchy as key symbol. For instance, the textbook for the homebound upper primary schools of 1921 (Goedert \& Reyland, 1921) contained numerous historic texts focused on the history of the Luxembourgian monarchy and its relationship to the population. With emerging discourses on perceived civic deficits that were suspected especially among the industrial workers, such notions of Catholic and national moral values were increasingly linked to the notion of combating social problems (hunger crises, housing shortage especially in the industrial South, and health problems such as flu pandemics). The hybrid procedures that were suggested, however, reveal the helplessness in finding causes to blame the social problems on and ways to combat them. Most strategies tried to hold a moral, civic, or knowledge deficit of the affected population responsible for the problem, one that could be countered with curricular adaptations (see Schreiber, Gardin, \& Tröhler, 2014); such deficits were traced back rhetorically to alleged cultural, economic, and biological factors. Thereby, they reveal a merely concealed perception of social problems as caused by behavioral deficits of the working class: "Unfortunately," we find the renown textbook Luxemburger Kinderfreund explaining to us, "from time to time, conflicts happen among many a coarse workers [...] especially, when the workers have drunk too much. If they were saving their hard and worrisome earned money, it would create a remedy for most of the later misery in the working-class environment" (Goedert \& Reyland, 1921, pp. 282f.)

Domestic and hygiene education were incorporated in the curriculum (ANLUx IP$1598,1889-1896)$. Implicitly assigning the responsibility for social problems to the women and their "deficits" to fulfill their domestic tasks, economic knowledge and education for thriftiness gained foremost importance in domestic education; the girls would have "to become aware of the benefits of her good housekeeping for the country, [...] and become a conscientious caretaker" (Mémorial A, 1922, pp. 980-984). Seeking additional salvation in the "simple" culture of peasantry, teachers like Joseph Meyers (1929) pleaded to center local folklore in postprimary teaching as the ultimate means against hedonism (pp. 133-137). Instruction in arithmetic also integrated calculation exercises to "counter uneconomic action of many people" with contexts of the public welfare institutions and the accountancy in family and municipality (ANLUX IP-1476, 1918). Additionally, economic notions of morality, like timeliness, accuracy, and work enthusiasm, were integrated into the moral frame, and school cooperation with the saving banks were considered a criterion of success by the local school authorities (see ANLux IP-597, 1893).

- Another pattern that directed postprimary education towards practical life was the intensively labored and highly differentiated design towards local and professional needs, including agriculture in the North, viticulture in the East, industrial 
education in the South, and commercial education in the capital (ANLUx IP-1598, 1878-1896). With the curricular provisions being highly flexible from region to region, several subjects found entrance to the curricula, such as civic instruction, technical drawing, and accountancy, and existing subjects were modified for professional needs, such as mathematics (ibid.). The curriculum here did not proceed in a systematic way, but covered only what was "at any rate characteristic at a specific place": "[t]he intuitive education may not be cut to the same form for urban and rural children. With a wise limitation of content [...], it is also possible for the 'weak in spirit' to achieve vivid thinking" (ANLux IP-1476, 1920).

Hence, continuing courses had no timetables or schedules available. Only drafts were provided on how professional preparations could interact with other matters. For rural schools, for instance, three focuses of the curriculum were designated: first, the peasant and his fields; second, the peasant and his animals; third: the peasant in family, commune, and state (ANLUx IP-1476, 1920). The only matters explicitly excluded from the canon of subjects were the ancient languages, which were reserved for secondary schools (Mémorial A, 1878, p. 225).

The strongest regional differentiation showed in the subjects that were considered relevant for the economic interplay of the regions. Accounting, for instance, ranged from "the regulations and maintenance for books of the vine-grower" in the wine village Remich $(A N L u x I P-1598,1881)$ to the "accountancy of the peasant" in rural Fels $(A N L$ Lx IP-1598, 1885). Industrial innovations such as machines, their construction, and their functions based on steam, electricity, and magnetism were commended with extensive explanations according to the local industries (for example, ANLUx IP-1598, 1883-1884). Motives of "work" epitomized the idea of progress of the Luxembourgian people and strengthened the ideal of individual and national autarchy which showed, for instance, in the promotion of thrifty saving and the saving banks especially in the continuing schools, which had closely worked together with the saving banks and had partially been funded by local banks (Luxemburger Schulbote, 1883, p. 45).

This localism in dependence on the profession was enforced by reforms pleading for the primary school to become a "work school," which led to an even stronger regionalization. The upper primary school reforms of 1916 and 1939 aimed at orienting school closer to cultural, local, and economic needs, realizing, for example, demands for English lessons and for applied instead of "pure" mathematics. While in 1916 the upper primary teachers did not want their schools to become economic regional schools, from 1936 onwards they asked for an even stronger regionalization (Wagner, 1936, p. 40). The suggestions for courses included agricultural or commercial accounting, horticulture and agriculture, mechanics, electricity, technology, and mining, as well as courses for floor men, shop assistants, and construction workers.

Therefore, one can say that students in postprimary schools were formed to be homebound Christian farmers, workers, and artisans. Even the textbooks for postprimary schools were strictly limited to the aforementioned patterns. For example, 
Die Fortbildungsschule für Handwerker (Wies, 1868) contained 250 pages, half of which were dedicated to religious history, with the other half containing practical instructions on how to write letters to civil services and a short summary of laws that could be relevant for artisans. Most of the books for postprimary schools showed the same characteristics throughout the following century: they showed that citizenship education was primarily meant for students of lower classes with lower school success - an idea that can still be found in Luxembourgian curricula today - and they linked patriotism and a specific homeland knowledge to topics of practical knowledge and Catholic morals in a very idiosyncratic way.

These principles of postprimary education did not result from a broad discourse including the affected population, but from projections of educational content, that in the view of the educational elite were missing for the "rest." It was the educational elite, members of the local councils and the commission of instruction, who determined what education was needed in the lower school branches, built on educational ideas that they strictly rejected for themselves in "their" secondary schools.

\section{International education for Luxembourg's "cosmopolitan" elite}

Secondary schooling in Luxembourg appears to be highly international at first glance, judging from several studies commissioned about schooling in neighboring countries, especially in the first decade of the 20th century. Indeed, reforms of the secondary schools referred mainly to the practice of schooling in neighboring countries; for over the past two centuries, curriculum research in Luxembourg was almost exclusively initiated from within the schools. The agents of reform here came from the practice of schooling, and they referred to the practice elsewhere, which was not least made possible by the exchange of international Catholic concepts of humanist education. Hence, the Luxembourgian secondary schools were oriented towards German neohumanist Gymnasien, but also included influences from France and Belgium. However, the international orientation of Luxembourg's secondary schools and its strong social differentiation emerged from a specific national situation. As a small country, Luxembourg could not serve its students with a proper university, so the entrance requirements of the universities abroad shaped the curriculum of the Luxembourgian schools anxious about their competitiveness.

During the whole long nineteenth century and beyond, education here was equated with "universal, general education," "all encompassing mental education," and "humanist education," which was constructed in opposition to "realist" education (Lanners 1927, p. 3). Humanist approaches to education and selective measures were still maintained in distinction from other branches through concerns of an alleged cultural regress (see, for example, ANLux IP-605, 1475, IP-630; 1916-1929). In this perception, education was not meant to be practical at all.

The humanist orientation, seeing Bildung as an end in itself, influenced the curriculum throughout the list of subjects: 
- For example, history foremost meant ancient history, on which more than half of the history program was spent; focal topics of the programs and syllabi were the history of Asian people and the history of ancient Greece and the Roman Empire (ANLux IP-601, 1889). The history curriculum was built on three major cores: ancient world history, national medieval history, and modern European history, the latter with a focus on French history (ANLux IP-636, IP-596, IP-598, 18891894). With this, it combined the cosmopolitan humanist focus on antiquity with the tale of the thousand-years-continuity of the Luxembourgian nation since its glorious beginning in the Middle Ages and its European embedding in economic and cultural regards in the times of the modern nation-state.

- The curricular content of the natural sciences was both oriented towards the later elite professions and chosen according to the perceived capability to sharpen the student's aesthetic senses and to the formal, ethic, and aesthetic educational "value," namely in the disciplines evolving around botanic lessons (Klein, 1897). Unlike in the upper primary schools, physics - with significantly fewer lessons than abroad - was not as important as chemistry, which contained cosmography and geology lessons of a scientific rigor (ANLux IP-596, 1889; IP1598, IP-636, 1895-1908).

- Language education stood in the center of the curriculum. Lessons in ancient languages which provided the "most precious blessings still for the present age" (Luxemburger Wort, 14 August 1922) occupied a huge part of the lessons; in 1889, for instance, eight hours per week were scheduled for Latin in all classes beyond the preparatory class (ANLux IP-596, 1889). In the five upper classes, the education in both classic languages summed up to twelve lessons per week out of 27-30 total weekly lessons (ibid.; IP-605, 1916-1929). Moreover, Latin lessons generally were taught in the first hours of every day (see, for example, ANLUx IP595, 1879; IP-596, 1889; IP-597, 1894). "Strengthen Latin" was the prominent slogan (as described in ANLux IP-596, 1888) that led to a series of measures to enforce Latin education foremost in the lower grades (ANLux IP-595, 1881; see also ANLux IP-596, 1888). Even though in the last two decades of the 19th century some attempts were made to enforce the modern languages (ANLUX IP$2369,1886)$, the dominance of Latin education was contested neither in public nor in professional discourse, and school libraries were filled with collections of ancient authors (ANLUx IP-595, 1879). Greek education admittedly was more contested, but the teachers' conferences especially saw themselves as defenders of a common European culture based on ancient values, countering strives for "material goods" in education with the tragic fate of the defeated Punic cities Tyrus and Carthago (Luxemburger Wort, 7 January 1889). In this perspective, only Greek education was able to form the character and the aesthetic knowledge of the students (Speck, 1889). Though the ministry tried to reduce Greek lessons, none of these attempts obtained validity (ANLux IP-596, IP-597, 1889-1892).

Another way to prepare the students for their stay abroad, but also to distinguish 
them from the lower school tracks, were the teaching languages, that - unlike in postprimary schooling - established a multilingual setting of instruction. The school law of 1861 had declared an "equilibrium" of German and French as teaching languages (Mémorial $A, 1861$, p. 80), a parity specified by ministerial regulations between 1878 and 1895 that fixed German as the language of instruction for religion, German, Greek education, and geography and history in the lower grades; and French for French itself, math, history (in the upper grades), geography, natural sciences, and accounting. Latin was taught in both languages; grammar was covered in German, but the translation and the literary analysis were delivered in French as a "most appropriate" instrument (ANLux IP-597, 1895).

Hence, it showed that German was meant to be the teaching language for rather practical content, and French for the mediation of high cultural values and aesthetics, but also as official corresponding language of an educational elite. This demonstrates the twofold character of the national educational elite, which distinctively invented itself as cosmopolitan citizens, yet concurrently, in the sense of an imagined community, integrated the social bilingualism - that did not contain a native background - in the national identity construction, officially celebrating it as a common trait of Luxembourg's idiosyncratic "mixed culture" (Péporté et al., 2010). It showed that the cosmopolitanism and internationality of secondary education served better as legitimation and distinction inwards than outwards. Also inherent in such a notion of cosmopolitanism is a differentiating gradient of educational sort within the Luxembourgian state, in distinction of those who do not have cosmopolitan skills and knowledge available and who also were not regarded as in need of these qualities, as their sphere is a homebound one. Behind the perceived cosmopolitanism and internationality of the elite, it was again the national logic of competitiveness responsible for this quite unchallenged international habitus. It was still agreed that the other nations were not a determining reference: "Does the sun only shine in France or Germany?" (ANLux IP-584, 1884).

\section{Conclusion and outlooks}

From its historical beginnings, citizenship had not been a concrete "recipe to be followed" (Friedrich, 2013, p. 26). It showed that there did not exist a consistent ideal of the Luxembourgian citizen, but different kinds of citizens according to the students' later function in societal life. Differences in citizenship construction could be found in the dualism between the ideal of a general secondary cosmopolitan, humanist "universal" education in terms of abstract Bildung for the perfection of the individual that also served to reproduce a strong educational elite, and the postprimary school ideal of homebound practically oriented, "realist" education as concrete Volksbildung.

While this supported the construction of an educational elite as resource and supporters of the state for demographic and political factors, it also fostered a differentiated imagined community not as a uniform, but as a harmonious society, allegedly based on and measured by studiousness. All negotiations thus envisioned curricula as adaptable to local, professional, and other societal conditions. Curricular 
sources depicted a harmonious collaboration not only of the different Luxembourgian regions. Different economies were claimed to work harmoniously together in favor of a stable, strong, and independent Luxembourgian state and a harmony between economy and culture. But most of all, the different school branches were staged as complementing each other (see, for example, Goedert \& Reyland, 1921, p. 281).

The historical analysis hence showed that both equalization and differentiation were essential parts of the construction of citizens in Luxembourg, yet the kinds of differentiation and equalization emerged from a national context and stayed persistent throughout the centuries. Their ponderousness can be explained by the tendency of modern nation-states to legitimate them culturally or morally, nationally or internationally: cumbersome, once established, this legitimation cannot easily be withdrawn after short periods of time. While postprimary school curricular discussions were often driven by the effort for mostly economic progress, secondary schools' curricular discourses were as frequently triggered by and legitimated with the fear of cultural regress. Under the assumptions of a European culture, the international orientation of the educated bourgeoisie and its aspirations in the 19th and 20th centuries to create a line between the individual, the national, and the global could likewise be understood as a cosmopolitan manifestation of nationalism, one that served mostly as an inward construction to create a distinction from the homebound "rest." Patterns of national identity and concerns about national competitiveness also triggered Luxembourgian educational discourses to take up discussions from abroad and enact education as international or cosmopolitan.

Recent Luxembourgian reforms of the twentieth and twenty-first century still show a persistence of the previously described elements, and these are not just historic left-overs in a changed and changing system; they were negotiated in specific national discourses on national progress (see Lenz, Rohstock, \& Schreiber, 2013). With these historical insights in mind, we - as hitchhiking researchers that come across the historical notion of citizenship from other times and spaces - might give its interpretation further Deep Thought.

\section{Archival sources}

Archives Nationales de Luxembourg (ANLux). (1839-). Portfolio Instruction Publique.

Escher Tageblatt: Demokratisches Organ für die Interessen des Kanton Esch (Variations: Tageblatt; Tageblatt. Zeitung fir Letzebuerg.) (1913). Esch, Luxembourg: Schroell. Luxemburger Schulbote: eine Zeitschrift, zunächst für die Schullehrer des Grossherzogthums Luxemburg bestimmt (1844-1942). Luxembourg.

Luxemburger Schulfreund: Bulletin de l'Union catholique des instituteurs et institutrices du Grand-Duché de Luxembourg. (1872-1939). Luxembourg.

Luxemburger Wort: Für Wahrheit und Recht. (1848-). Luxembourg: Saint-Paul.

Mémorial du Grand-Duché de Luxembourg. Series A: Recueil de legislation. (1842-).

Luxembourg: Gouvernement. 


\section{References}

Adams, D. (1981). The hitchhiker's guide to the galaxy. New York, NY: Harmony.

Anderson, B. (1983). Imagined communities. Reflections on the origin and spread of nationalism. London, England: Verso.

Anderson-Levitt, K. M. (2003). A world culture of schooling? In K. M. Anderson-Levitt (Ed.), Local meanings, global schooling: Anthropology and World Culture Theory (pp. 1-20). New York, NY: Palgrave.

Arnot, M. et. al. (1996). Teachers, gender and discourses of citizenship. International Studies in Sociology of Education, 6(1), 3-35.

Balibar, É. (2004). We, the people of Europe? Reflections on transnational citizenship. (J. Swenson, Trans.). Princeton, NJ, and Oxford, England: Princeton University Press. [French original: Nous, citoyens d'Europe? Les frontières, l'État, le people. (2001).]

Bénéï, V. (2005). Manufacturing citizenship: Education and nationalism in Europe, South Asia and China. London, England: Routledge.

Benhabib, S. (1996). Toward a deliberative model of democracy. In S. Benhabib (Ed.), Democracy and difference: Contesting the boundaries of the political (pp. 67-94). Princeton, NJ: Princeton University Press.

Braudel, F. (1949). La Méditerranée et le monde méditeranéen à l'epoque de Philippe II. Paris, France: Habilitation.

Cogan, J., \& Derricott, R. (2000). Citizenship for the 21st century: An international perspective on education. London, England: Kogan Page.

Cruikshank, B. (1999). The will to empower: Democratic citizens and other subjects. Ithaca, NY: Cornell University Press.

De Oliveira Andreotti, V., \& Mario de Souza, L. (Eds.) (2012). Postcolonial perspectives on global citizenship education. New York: NY: Routledge.

Falk, R. (2000). The decline of citizenship in an era of globalization. Citizenship Studies, $4(1), 5-17$.

Der Fortbildungsschüler im Rechts- und Pflichtstaat: Verfassung, Gesetze und Pflichten. Leitfaden zum Gebrauch in den Fortbildungs- $u$. Handwerkerschulen und technischen Kursen. (1916). Luxembourg: Soupert.

Friedrich, D. (2013). Democratic education as a curricular problem: Historical consciousness and the moralizing limits of the present. New York, NY: Routledge.

Goedert, N., \& Reyland, R. (1921). Luxemburger Kinderfreund. Neues Lesebuch für die Oberstufe der Primärschulen. Luxembourg.

Gowar, C. (2008). Globalization and the transformation of citizenship (Doctoral dissertation). Rutgers University, New Brunswick, NJ.

Haydon, G. (2003). Aims in citizenship education: Responsibility, identity, inclusion. In A. Lockyer, B. R. Crick, \& J. Annette (Eds.), Education for democratic citizenship: Issues of theory and practice (pp. 78-88). Aldershot, England: Ashgate.

Heater, D. (2003). A history of education for citizenship. London, England: Routledge.

Hobsbawm, E., \& Ranger, T. (1992). The invention of tradition. Cambridge, England: Cambridge University Press. 
Ichilov, O. (Ed.). (1998). Citizenship and citizenship education in a changing world. London, England: Woburn Press.

Joppke, C. (2007). Transformation of citizenship: Status, rights, identity. Citizenship Studies, 11(1), 37-48.

Kamens, D. H. (2012). Beyond the nation-state: The reconstruction of nationhood and citizenship. Bingley, England: Emerald Limited.

Klein, E. (1897). Die Flora der Heimat sowie die hauptsächlichsten bei uns kultivierten fremden Pflanzenarten biologisch betrachtet. Programm herausgegeben am Schlusse des Schuljahres 1896-1897 (pp. 1-170). Diekirch, Luxembourg: Gymnase grand-ducal.

Koenig, L. (1914). De l'éducation patriotique. Luxembourg: Mémoire pédagogique.

Kymlicka, W. (2001). Politics in the vernacular: Nationalism, multiculturalism and citizenship. Oxford, England: Oxford University Press.

Lanners, N. (1921). Vom Bildungswert der Wissenschaft. Programm herausgegeben am Schlusse des Schuljahres 1920-1921 (pp. 3-28). Echternach, Luxembourg: Gymnase grand-ducal.

Lemberg, E. (1964). Nationalismus. Vol. 2. Reinbek bei Hamburg, Germany: Rowohlt.

Lenz, T., Rohstock, A., \& Schreiber, C. (2013). Tomorrow never dies: A socio-historical analysis of the Luxembourgish curriculum. In W. Pinar (Ed.), International handbook of curriculum research (2nd ed.). (pp. 315-328). New York, NY: Routledge.

Marshall, T. H. (1950). Citizenship and social class. London, England: Cambridge University Press.

Meyer, J. W., Ramirez, F. O., \& Soysal, Y. N. (1992). World expansion of mass education, 1870-1980. Sociology of Education, 65(2), 128-149.

Meyers, J. (1929). Volkskunde im Unterricht. Jahrbuch der Luxemburgischen Sprachgesellschaft, 133-137.

Olson, K. (2008). Constructing citizens. Journal of Politics, 70(1), 40-53.

Pateman, C. (1988). Wollstonecraft's dilemma: Equality vs. difference. In C. Pateman (Ed.), The disorder of women: Democracy, feminism and the welfare state (pp. 196197). Cambridge, England: Polity.

Pateman, C. (1992). Equality, difference, subordination: The politics of motherhood and women's citizenship. In G. Bock \& S. James (Eds.), Beyond equality and difference: Citizenship, feminist politics and female subjectivity (pp. 14-27). London, England, and New York, NY: Routledge.

Péporté, P., Kmec, S., Majerus, B., \& Margue, M. (2010). Inventing Luxembourg. Representations of the past, space and language from the nineteenth to the twentyfirst century. Leiden, Netherlands: Brill.

Popkewitz, T. (2008). Cosmopolitanism, the citizen and processes of abjection: The double gestures of pedagogy. In M. Peters, H. Blee, \& A. Britton (Eds.), Global citizenship education: Philosophy, theory and pedagogy (pp. 133-153). Rotterdam, Netherlands: Sense.

Prokhovnik, R. (1998). Public and private citizenship: From gender invisibility to 
feminist inclusiveness. Feminist Review, 60, 84-104.

Richardson, D. (1998). Sexuality and citizenship. Sociology, 32(1), 83-100.

Richardson, G. H., \& Blades, D. W. (Eds.). (2006). Troubling the canon of citizenship education. New York, NY: Peter Lang.

Rose, N. (1999). Governing the soul: The shaping of the private self ( $2^{\text {nd }}$ ed.). London, England: Free Association Books.

Rose, N., \& Miller, P. (1992). Political power beyond the state: Problematics of government. The British Journal of Sociology, 43(2), 173-205.

Schreiber, C. (2014). Curricula and the making of the citizens: Trajectories from $19^{\text {th }}$ and $20^{\text {th }}$ century Luxembourg (Doctoral dissertation). University of Luxembourg.

Schreiber, C., Gardin, M., \& Tröhler, D. (2014). Curriculum unter beschuss? Luxemburger schulreformen im kontext des Ersten Weltkrieges. In C. Roemer, et al. (Eds.), Livre 1ere Guerre Mondiale (pp. 127-137). Luxembourg: capybarabooks.

Speck, J. (1889). Zur Frage über den griechischen Unterricht: Eine luxemburgische Schulfrage. Programm herausgegeben am Schlusse des Schuljahres 1888-1889 (pp. 1-15). Echternach, Luxembourg: Progymnase grand-ducal.

Tröhler, D., Popkewitz, T., \& Labaree, D. F. (Eds.) (2011). Schooling and the making of citizens in the long nineteenth century: Comparative visions. New York, NY: Routledge.

Wagner, M. (1935). Heimatkundlicher Erziehungsunterricht. Luxembourg: Schroell.

Wagner, M. (1936). Die Reform der Oberprimärschulen im Zusammenhang unseres Unterrichtswesens. Luxembourg: Schroell.

White, H. (1981). The value of narrativity in the representation of reality. In W. J. T. Mitchell (Ed.), On narrative (pp. 1-23). Chicago, IL: University of Chicago Press.

Wies, N. (1868). Die Fortbildungsschule für Handwerker. Luxembourg: V. Bück. 